\title{
PATHOLOGICAL AND BACTERIOLOGICAL STUDIES ON BRONCHOPNEUMONIA CAUSED BY PSEUDOMONAS AERUGINOSA IN COMMERCIAL RABBITS IN ALEXANDRIA GOVERNORATES.
}

\author{
Sanaa A. El-shamy * , Walaa I. Ahmed ${ }^{* *} \&$ Shahera M. Rashad ${ }^{* * *}$. \\ Animal Health Research Institute * Pathology department, \\ *** Bacteriology department, Alexandria ${ }^{* * *}$ Pathology department, Assiut.
}

\begin{abstract}
Pseudomonas aeruginosa is an aerobic Gram- negative bacterium which has emerged as one of the most problematic nosocomial pathogens. To characterizes Pseudomonas aeruginosa strains that are wide spread in rabbits, 50 rabbit samples were collected from five different commercial private rabbit farms at Alexandria governorate showing symptoms of respiratory manifestation based upon culture methods coupled with biochemical tests, were used in this study. The results showed that, seven isolates of Pseudomonas aeruginosa recovered from 50 diseased rabbits with a percentage of $14 \%$ (two from lung, two from heart blood, one from liver, one from kidney and one from intestine), they were catalase, oxidase positive whereas negative for methyl red, Vogas proskaeur and indole; however; some of these methods are time consuming and may be not very accurate whereas API2OE is rapid method which performs at least 20 different biochemical tests at once. To study the suscepaility of tested stains of Pseudomonas aeruginosa to 11 different antibiotics using disk agar diffusion the result showed that all Pseudomonas aeruginosa strains were highly sensitive to ciprofloxacin, tobramycin with sensitivity of $100 \%$ followed by cefazolin, amikacin, gentamicin and colistin sulphate with a percentages of $85.7 \%, 71.4 \%, 71.4 \%, 42.85 \%$, respectively. On the other hand, the isolates were highly resistant to amoxacillin, erythromycin and streptomycin and with an incidence of $100 \%$ for all, followed by chloramphenicol, trimethoprim sulphamethaxazole $(85.7 \%$ each) then, clostin sulphate, gentamicin
\end{abstract}


(28.75\% each) followed by amikacin 14.28\%. In attempting to further identification of Pseudomonas aeruginosa strains at the DNA level, polymerase chain reaction (PCR) was used based on specific primer for oprL genes, the result showed that positive PCR as the agar gel electrophoresis of the PCR products showed that all them produced a DNA fragment or band at the 504 bp band. PCR has found to be rapid and more sensitive and specific in identification of Pseudomonas aeruginosa.

The lungs of all examined rabbits were congested, oedematous, scattered firm, yellowish areas of consolidated and indurated heamorrhagic areas. Multifocal necrosis presents in lung, liver, kidney and spleen. Microscopic examination demonstrated both parenchymal and bronchial changes. The lungs were extremely hyperemic and showed marked intrapulmonary heamorrhage and oedema, extensive mononuclear cell infiltration. Alveolar dilatation, septal wall destruction and lymphoid tissue hyperplasia. Pulmonary blood vessels were congested and surrounded by mononuclear cells infiltration. Bronchi and Bronchiolar walls were thickened by mononuclear cells infiltration. Epithelial degeneration with loss of bronchial cilia. The cellular infiltration include macrophages accompanied by lymphocytes with occasional plasma cells and multinucleated giant cells. The kidney showed degenerative changes in cortex and medulla, proliferation and accumulation of cells inside the Bowman's capsules and or contraction of the glomerulus. Renal tubules showed signs of degeneration, focal areas of necrosis. Liver showed congestion, hyperemia and widening of hepatic sinusoids. Extravasations of erythrocytes into the hepatic parenchyma. There was intercellular hemorrhage and distortion of hepatic cords and congestion in hepatoportal blood vessels. Spleen showed no separation between white and red bulb element, exhaustion of lymphocytes of hematopoietic element. Marked interstitial heamorrhage specially under splenic capsule.

Keywords: Pseudomonas aeruginosa, PCR (Polymerase Chain reaction), histopathology, microbiology. 


\section{INTRODUCTION}

The domestic rabbits have been considered as one of the most important farm animals. The process of rabbit production in Egypt faces great economic losses mainly due to microbial infections which lead to high mortality rate (Blanco et al., 1994). Pseudomonas aeruginosa is an aerobic, non sporulating, Gram-negative, motile bacterium. Its motility is through polar flagella. This bacterium is positive to the oxidase and catalase tests; it is classified within the heterogeneous group of "non fermenting" bacteria. Pseudomonas aeruginosa is considered an opportunistic pathogen as it causes infection in immunodepressed subjects or in those with faulty homeostasis mechanisms (Walker.,1998; Kiska and Gilligan 1999). This bacillus is found in warm, moist environments, and can be frequently isolated from soil, water, and occasionally from normal skin (Percy and Barthold 1993). Pseudomonas aeruginosa is an important etiologic agent of a variety of infectious diseases (Gray and Kreg1979; Gilleland et al., 1988; Iwata and Sato 1991). The bacteria may cause broad spectrum infections such as urinary, respiratory, gastrointestinal tract, eyes, and other sites. Also, it contributes to high morbidity and mortality rates (Hotack and Majt, 1997). Pulmonary infection with Pseudomonas aeruginosa may be accompanied by severe tissue damage because this organism produces several virulence factors in mammalian hosts and these contribute to the pulmonary tissue damage (Woods and Sokol, 1986). The rapid systemic dissemination of Pseudomonas aeruginosa is associated with the fact that some strains cause acute lung epithelial injury by inducing the necrosis of the lung epithelium (Wiener-Kronish et al., 1993). However, there have been a few reports of naturally occurring Pseudomonas 
aeruginosa in rabbits, guinea pigs, non human primates (Buret and Cripps, 1993). Pseudomonas aeruginosa was isolated from nasal passages, oropharynx, large intestines and skin in many healthy rodent colonies (Iwata et al., 1987).

Pseudomonas aeruginosa continues to be a major cause of resistance because of its high intrinsic resistance to antibiotics it has been demonstrated that this intrinsic resistance arises from the combination of unusually restricted outer membrane permeability and secondary resistance mechanisms such as energy-dependant multidrug efflux and chromosomally encoded periplasmic betalactamase given this high natural resistance and mutational resistance to most classes of antibiotics can readily araised (Hancock and Speert ., 2000).

In general, diagnosis of Pseudomonas aeruginosa infection is based on isolation of the pathogen, then perform biochemical tests, pathogenicity tests, and serological tests (Rahme et al., 1997). Such tests require one or several weeks before final confirmation is obtained. Currently, molecular assays based on 16S rDNA, 16S-23S rDNA, ITS, ETA, Aic, algD, oprI, oprL, tox A, gyr B, and ecfx genes region are generally used for the detection and identification of Pseudomonas aeruginosa, but there have been serious defects in identification and diagnosis of Pseudomonas aeruginosa isolates in that these assays also detect other Pseudomonas species, or do not produce amplicons from Pseudomonas aeruginosa strains (Heyon et al., 2013).

The aim of the present study was to determine the incidence of bronchopneumonia caused by Pseudomonas aeruginosa in commercial rabbits in Alexandria , Egypt and to apply a rapid and simple technique for the specific detection and identification of Pseudomonas aeruginosa and evaluate the histopathological lesions of such specimens. 


\section{MATERIAL AND METHODS}

\section{1- Collection of rabbits samples:}

A total of 50 rabbits (ages ranged from 6-8 weeks) were collected from different private rabbit farms at Alexandria governorate. Samples were taken from rabbits suffering clinically from respiratory manifestation (sneezing, loud raspy breathing, nasal discharges, mucous expectoration, fever dyspnea and coughing), emaciation, weakness and reduced body weight. The morbidity rate reached $30 \%$ and the mortality rate was up to $10 \%$ in the flock as was reported by veterinarians. Pseudomonas aeruginosa were Isolated from specimens of lung, liver, heart blood, kidney and intestine.

\section{2- Bacteriological examination:}

\section{1- Isolation of Pseudomonas aeruginosa:}

Specimen from lung, liver, heart blood and intestine were inoculated on nutrient broth and incubated at $37^{\circ} \mathrm{C}$ overnight. Then all samples were streaked onto nutrient agar and MacConkey 's agar media, then incubated aerobically at $37^{\circ} \mathrm{C}$ for $24-48$ hours. Suspected colonies were picked up and purified by further subculturing on nutrient agar. All purified colonies were streaked onto slope agar and then preserved on semisolid nutrient agar for further identification. The phenotyping characteristics of pure isolates of Pseudomonas aeruginosa was described after Gram staining, pigments production after incubation at $42{ }^{\circ} \mathrm{C}$ for 24 hours and the biochemical tests were done according to MacFaddin (2000) which include Catalase, Oxidase, Indole production, Methyl red, Vogas proskaeur and Citrate utilization, Urea hydrolysis and 
motility, then API20E system used for biochemical test which consists of 20microtubes, containing dehydrated substrates. During incubation, metabolism produces color changes that are either spontaneous or revealed by the addition of reagents and the identification is obtained by referring the analytical profile index.

\section{3- Antibacterial sensitivity of Pseudomonas aeruginosa isolates:}

\section{1- Standard disk agar diffusion test:}

It was done according to Ferraro et al., (2000) which based on Muller Hinton medium. The antibacterial disks which used to determine the sensitivity and resistance pattern of Pseudomonas aeruginosa isolates were obtained from Oxoid manufacturing companies. The disks were listed in table (1).

Table (1) : Zone diameter interpretative standards :

\begin{tabular}{|c|c|c|c|c|}
\hline \multirow{2}{*}{ Antibacterial used } & \multirow{2}{*}{$\begin{array}{l}\text { Potency of the } \\
\text { disk }\end{array}$} & \multicolumn{3}{|c|}{ Inhibation zone diameter(mm) } \\
\hline & & Sensitive & Intermediate sensitive & Resistant \\
\hline Amikacin & $10 \mu \mathrm{g}$ & $\geq 14$ & $12-13$ & $\leq 11$ \\
\hline Amoxacillin & $25 \mu \mathrm{g}$ & $\geq 31$ & $23-30$ & $\leq 22$ \\
\hline Chloramphenicol & $30 \mu \mathrm{g}$ & $\geq 18$ & $13-17$ & $\leq 12$ \\
\hline Cefazolin & $30 \mu \mathrm{g}$ & $\geq 18$ & $15-17$ & $\leq 14$ \\
\hline Ciprofloxacin & $5 \mu \mathrm{g}$ & $\geq 21$ & $16-20$ & $\leq 15$ \\
\hline Colistin sulphate & $10 \mu \mathrm{g}$ & $\geq 11$ & $9-10$ & $\leq 8$ \\
\hline Erythromycin & $15 \mu \mathrm{g}$ & $\geq 18$ & $114-17$ & $\leq 13$ \\
\hline Gentamicin & $10 \mu \mathrm{g}$ & $\geq 15$ & $13-14$ & $\leq 12$ \\
\hline reptomycinSt & $10 \mu \mathrm{g}$ & $\geq 15$ & $12-14$ & $\leq 11$ \\
\hline $\begin{array}{l}\text { Trimethoprim } \\
\text { \&Sulphamethaxazole }\end{array}$ & $\begin{array}{c}1.25 \\
\& 23.75 \mu \mathrm{g}\end{array}$ & $\geq 16$ & $11-15$ & $\leq 10$ \\
\hline Tobramycin & $10 \mu \mathrm{g}$ & $\geq 14$ & $12-13$ & $\leq 11$ \\
\hline
\end{tabular}

Kafrelsheikh Vet. Med. J. Vol. 11 No. 1 (2013) 


\section{4- Detection of Pseudomonas aeruginosa by PCR:}

\section{1- DNA extraction:}

DNA extraction from samples was performed using the Qiamp Mini kit (Qiagen, Germany, GmbH) with modifications from the manufacturer's recommendations. Briefly, $200 \mu$ l of the sample suspension was incubated with $10 \mu \mathrm{l}$ of proteinase $\mathrm{K}$ and $200 \mu \mathrm{l}$ of lysis buffer at $56^{\circ} \mathrm{C}$ for $10 \mathrm{~min}$.

After incubation, $200 \mu \mathrm{l}$ of $100 \%$ ethanol was added to the lysate. The sample was then washed and centrifuged following the manufacturer's recommendations. Nucleic acid was eluted with $100 \mu 1$ of solution buffer provided in the kit.

Oligonucleotide Primer: Primers used were supplied from Metabion (Germany) are listed in Table (2).

Table (2): PCR primers for amplification of oprL gene of Pseudomonas aeruginosa:

\begin{tabular}{|c|c|c|c|c|c|c|}
\hline Gene & $\begin{array}{c}\text { Primers } \\
5^{\prime}-3^{\prime}\end{array}$ & $\begin{array}{l}\text { Amplified } \\
\text { segment } \\
\text { (bp) }\end{array}$ & $\begin{array}{c}\text { Secondary } \\
\text { denaturation }\end{array}$ & $\begin{array}{l}\text { Annealing } \\
\text { temperature }\end{array}$ & Extension & Reference \\
\hline OprL & $\begin{array}{c}\text { f: 5'-ATG GAA ATG CTG } \\
\text { AAA TTC GGC-3' } \\
\text { r: 5'-CTT CTT CAG CTC } \\
\text { GAC GCG ACG-3' } \\
\end{array}$ & 504 & $\begin{array}{l}94^{\circ} \mathrm{C} \\
1 \mathrm{~min} .\end{array}$ & $\begin{array}{l}55^{\circ} \mathrm{C} \\
1 \mathrm{~min} .\end{array}$ & $\begin{array}{l}72^{\circ} \mathrm{C} \\
1 \mathrm{~min} .\end{array}$ & $\begin{array}{l}\text { Xu et al., } \\
2004\end{array}$ \\
\hline
\end{tabular}

\section{2- PCR amplification:}

Primers were utilized in a $25-\mu 1$ reaction containing $12.5 \mu 1$ of Emerald Amp Max PCR Master Mix (Takara, Japan), $1 \mu$ l of each primer of $20 \mathrm{pmol}$ concentration, $4.5 \mu \mathrm{l}$ of water, and $6 \mu \mathrm{l}$ of template. The reactions were performed in a Biometra thermal cycler. 


\section{3- Analysis of the PCR Products:}

The products of PCR were separated by electrophoresis on $2 \%$ agarose gel (Applichem, Germany, GmbH) in 1x TBE buffer at room temperature using gradients of $5 \mathrm{~V} / \mathrm{cm}$. For gel analysis, $15 \mu \mathrm{l}$ of the products was loaded in each gel slot. A 100bp DNA Ladder (Qiagen, Germany, $\mathrm{GmbH}$ ) was used to determine the fragment sizes. The gel was photographed by a gel documentation system (Alpha Innotech, Biometra) and the data was analyzed through computer software.

\section{5- Pathological Examination:}

Tissue specimens were collected after postmortem examination from lung, kidneys, liver and spleen. These samples were fixed in formalin $10 \%$ for at least $24-72 \mathrm{hrs}$, then washed with water, dehydrated, cleared, and embedded in paraffin wax. Section of 5 microns were stained with Heamatoxylin and Eosin for histological examination according to Bancrofts et al., (1996).

\section{RESULTS}

\section{Aetiological finding:}

\section{1- Frequency of distribution of Pseudomonas aeruginosa recovered from different organs of diseased rabbits:}

The bacteriological examination of 50 diseased rabbits individual (6-8 weeks) including lung, liver, intestine, kidney and heart blood, 7 isolates of Pseudomonas aeruginosa were recovered, with an incidence of $14 \%$ as shown in table (5). 
Pathological And Bacteriological Studies On ...

Table (5): Frequency of distribution of Pseudomonas aeruginosa recovered from different organs of diseased rabbits:

\begin{tabular}{|c|c|c|}
\hline \multirow{2}{*}{ Specimen Examined } & \multicolumn{2}{|c|}{ Diseased rabbits (50 rabbits) } \\
\hline & No. of isolates & \% of isolates \\
\hline Lung & 2 & 4 \\
\hline Liver & 1 & 2 \\
\hline Intestine & 1 & 2 \\
\hline Kidneys & 1 & 2 \\
\hline Heart blood & 2 & 4 \\
\hline Total & 7 & 14 \\
\hline
\end{tabular}

2- The antibacterial of Pseudomonas aeruginosa isolates recovered from diseased rabbits:

Results of this study are represented in table (6) where 7 isolates of Pseudomonas aeruginosa were tested against the same 11 selected antibacterial agents which showed that ciprofloxacin, tobramycin was the best antibacterial agent against isolates of Pseudomonas aeruginosa with sensitivity of $100 \%$ followed by cefazolin, amikacin, gentamicin and colistin sulphate with a percentages of $85.7 \%, 71.4 \%, 71.4 \%, 42.85 \%$, respectively. On the other hand, the isolates were highly resistant to amoxacillin, erythromycin and streptomycin and with an incidence of $100 \%$ for all.

Table (6): Antibacterial of Pseudomonas aeruginosa isolates recovered from diseased rabbits against some selected antibacterial agents:

\begin{tabular}{|c|c|c|c|c|c|c|}
\hline \multirow{2}{*}{$\begin{array}{c}\text { Antibacterial } \\
\text { Agents }\end{array}$} & \multicolumn{2}{|c|}{ Sensitive } & \multicolumn{2}{|c|}{ Intermediate sensitive } & \multicolumn{2}{|c|}{ Resistant } \\
\hline & No* & $* * \%$ & No* & $* * \%$ & No* & $* * \%$ \\
\hline Amikacin & 5 & 71.4 & 1 & 14.28 & 1 & 14.28 \\
\hline Amoxacillin & 0 & 0 & 0 & 0 & 7 & 100 \\
\hline Chloramphenicol & 0 & 0 & 1 & 14.28 & 6 & 85.7 \\
\hline Cefazolin & 6 & 85.7 & 0 & 0 & 1 & 14.28 \\
\hline Ciprofloxacin & 7 & 100 & 0 & 0 & 0 & 0 \\
\hline Colistin sulphate & 3 & 42.85 & 2 & 28.75 & 2 & 28.75 \\
\hline Erythromycin & 0 & 0 & 0 & 0 & 7 & 100 \\
\hline Gentamicin & 5 & 71.4 & 0 & 0 & 2 & 28.75 \\
\hline Streptomycin & 0 & 0 & 0 & 0 & 7 & 100 \\
\hline Trimethoprim \&Sulphamethaxazole & 0 & 0 & 1 & 14.28 & 6 & 85.7 \\
\hline Tobramycin & 7 & 100 & 0 & 0 & 0 & 0 \\
\hline
\end{tabular}

* Total number of tested Pseudomonas aeruginosa isolates was 7.

**Percentages were calculated in relation to the total number of the tested Pseudomonas aeruginosa isolates.

Kafrelsheikh Vet. Med. J. Vol. 11 No. 1 (2013) 


\section{3- Results of polymerase chain reaction of Pseudomonas aeruginosa:}

This test was used for further identification of seven isolates of Pseudomonas aeruginosa. The results of this test revealed that seven strains of Pseudomonas aeruginosa were positive for PCR as the agarose agar gel electrophoresis of the PCR products showed that all of them produced a DNA fragment or band with a 504 bp band as shown in the following photo (1).

\section{Photo (1):}

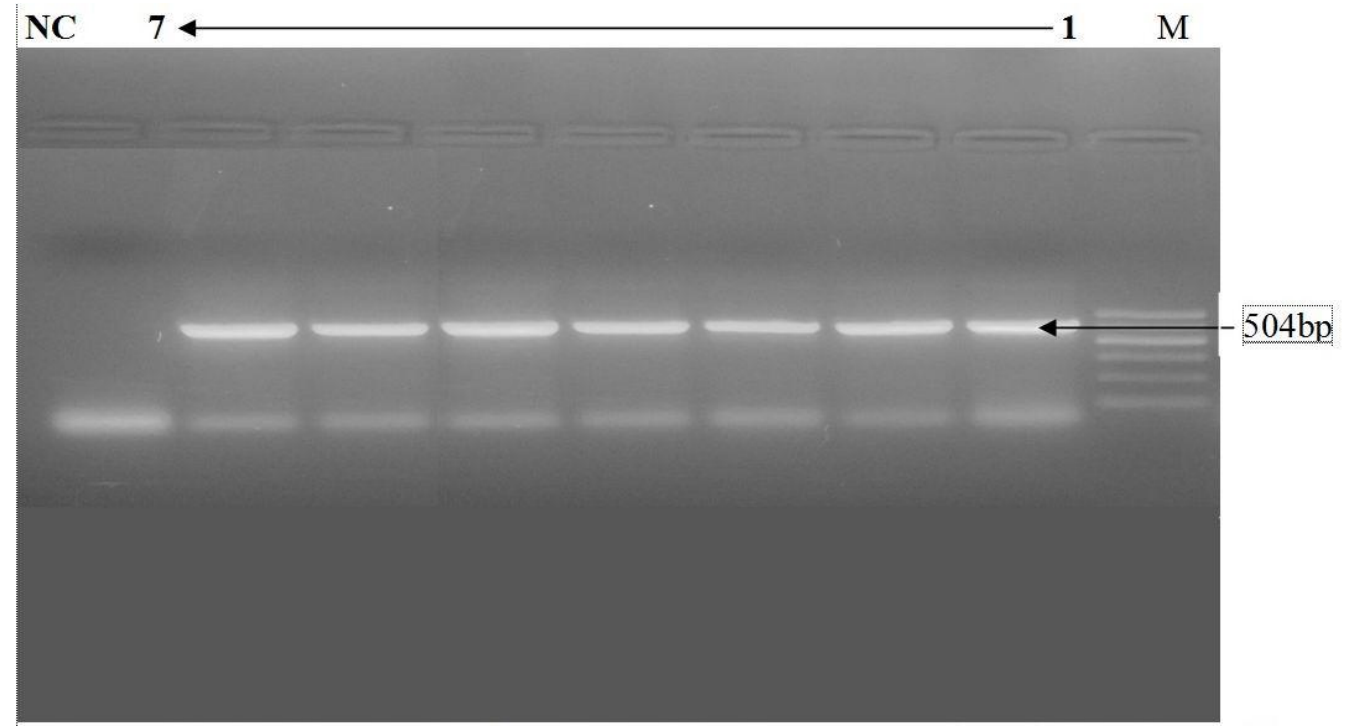

Agrose gel electrophoresis of PCR products of Pseudomonas aeruginosa isolates from rabbits.

Lanes : * M, mol wt marker(100-bp ladder, Qiagen, Germany, GmbH);

* 1-7 Indicate PCR products of seven isolates of Pseudomonas aeruginosa with a $504 \mathrm{bp}$.

* last no.(NC) : negative control (DNA added). 


\section{The histopathological examination:}

\section{Macroscopic finding:}

On dissection of both dead and slaughtered rabbits congestion of the upper respiratory passages were finding. The lungs of all animals were congested, heavy oedematous. Lungs showed scattered firm, yellowish areas of consolidated tissue mixed with numerous indurated heamorrhagic areas. The consolidated areas were either unilaterally or bilaterally located. Sagittal lung sections revealed extended lesions throughout the depth of the lung. Splenomegaly and visceral ecchymoses.

\section{Microscopic finding:}

\section{Lung:}

Microscopic examination demonstrated both parenchymal and bronchial changes. Lungs were extremely hyperemic and showed marked intrapulmonary heamorrhage and interstitial oedema (Fig. 1a). In the lung parenchyma, dense mononuclear cell infiltration accumulated in the alveolar spaces (Fig. 1b). Alveolar lumen contained accumulations of erythrocytes, extensive numbers of polymorph nuclear cells were observed (Fig. 1b). Extravasations of erythrocytes into the alveolar spaces were noticed (Fig. 1b). Large randomly distributed areas of necrosis were seen (Fig. 1c). In addition, some sections showed extensive infiltration and thickening of alveolar septa by mononuclear inflammatory cells were observed (Fig. 1b) and others showed alveolar dilatation and alveolar septa necroses reached to destruction of alveolar septum (Fig. 1c). Aggregations of inflammatory cells between the lung tissues prealveolar duct (Fig. 1c). Lung sections showed lymphoid hyperplasia, characterized mainly by expanded lymphoid tissue and occasionally by patchy lymphoid aggregates (Fig. 1d). 
Sanaa A. El-shamy et., al.
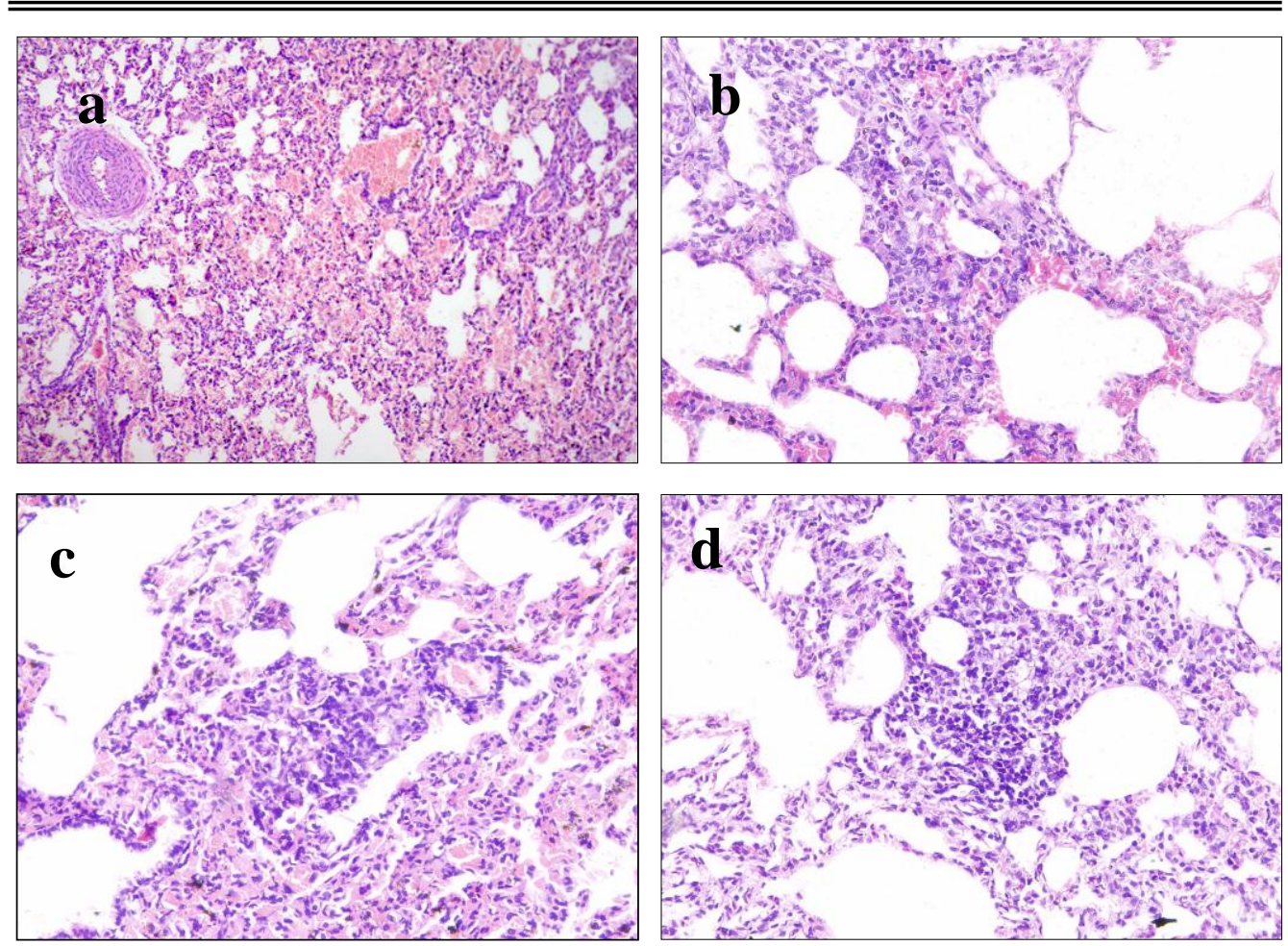

Fig. (1): Lung ofinfected rabbit showing (a X100) Heamorrhages, interstitial oedema, extravasations of erythrocytes into the alveolar spaces. (b X200) Massive accumulation of cellular infiltrations, over distension of alveoli and destruction of alveolar septum. (c X200) Aggregations of inflammatory cells at prealveolar duct. (dX200) Lymphoid hyperplasia. Hematoxylin and eosin stain.

Degenerative changes of the bronchial and bronchiolar epithelium were observed. Bronchial walls were thickened by mononuclear cells infiltration (Fig. 2a,b\&c). The main intrapulmonary bronchi showed accumulation of exudates and peribronchial mononuclear infiltration and alveolar necrosis was observed, (Fig. 2d). Hyperplasia of bronchial lymphatic tissues occurred (Fig. 2d). The airways were narrowed as a result of bronchial lymphatic tissues hyperplasia (Fig. 2e). The airways were surrounded by inflammatory cells (Fig. e). Bronchial changes including epithelial degeneration with loss of cilia, bronchial glands and goblet cell showed cellular degeneration (Fig. 2 f, g). 

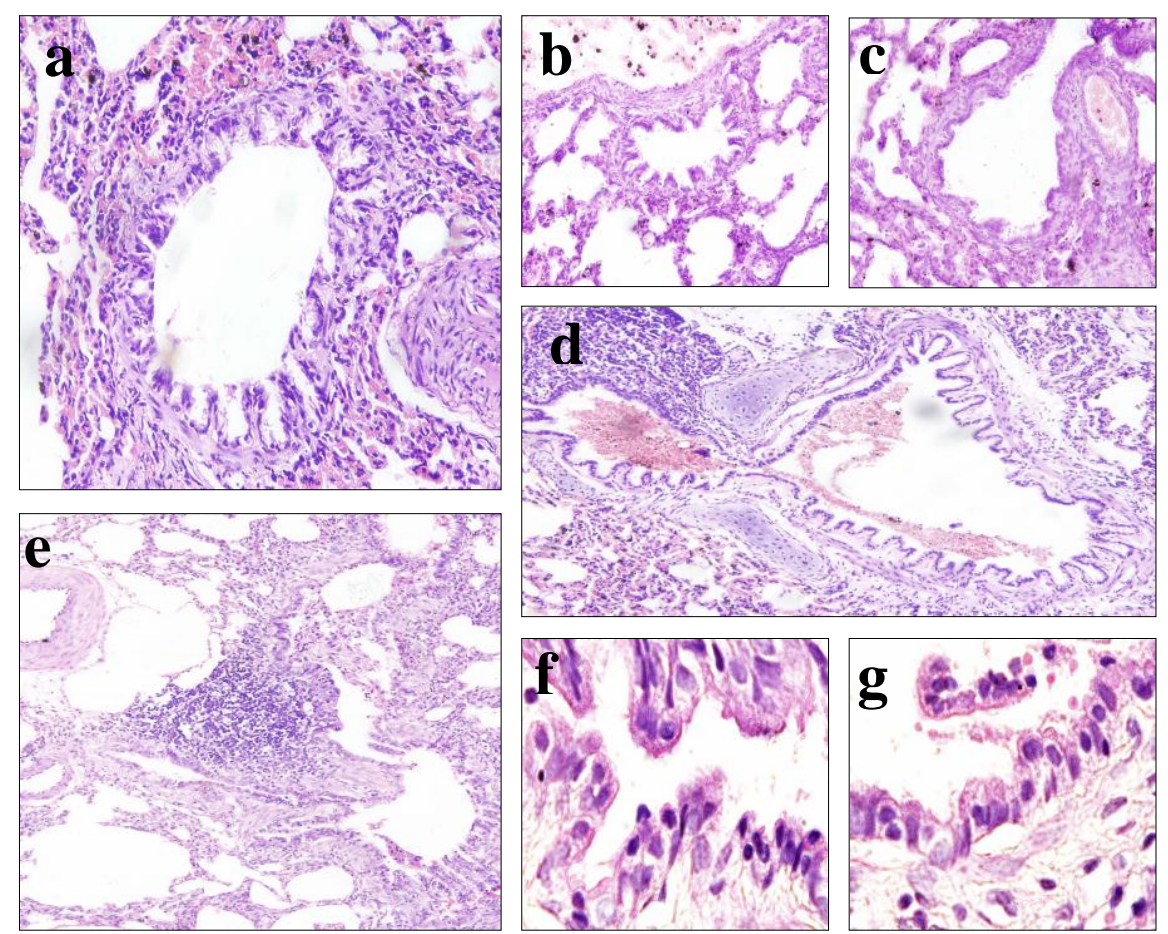

Fig. (2): Bronchi showing (a X200) massive inflammatory cells infiltrates within pulmonary Peribronchi. (b,c X200) The lumens of the bronchiole are narrowed. (d X100) The main intra-pulmonary bronchus showed peribronchial mononuclear cellular infiltration and hyperplasia of bronchial lymphatic tissues .(e X200) The airways were surrounded by inflammatory cells. (f,g X 1000) bronchial epithelial degeneration with loss of cilia. Hematoxylin and eosin stain

Pulmonary vessels were congested and surrounded by Perivascular edematous connective tissues contained an infiltrate of mononuclear cells (Fig. 3a). Lung sections showed lymphoid hyperplasia characterized mainly by expanded bronchus lymphoid tissue (Fig. 3a). Pulmonary arteries were showed smooth-muscle hypertrophy and progressive injury and necrosis (Fig. 3b). Endothelial cells showed progressive injury and necrosis (Fig. 3b). High endothelial veins were observed with proliferation of the cells (Fig. 3c). Macrophages, eosinophil, plasma cells and lymphocytes were seen around the bronchiole and within alveolar parenchyma (Fig.4 a, b \& c). Multinucleated giant cells and increase the number of platelets (Fig. 4 d, e \& f). 
Sanaa A. El-shamy et., al.
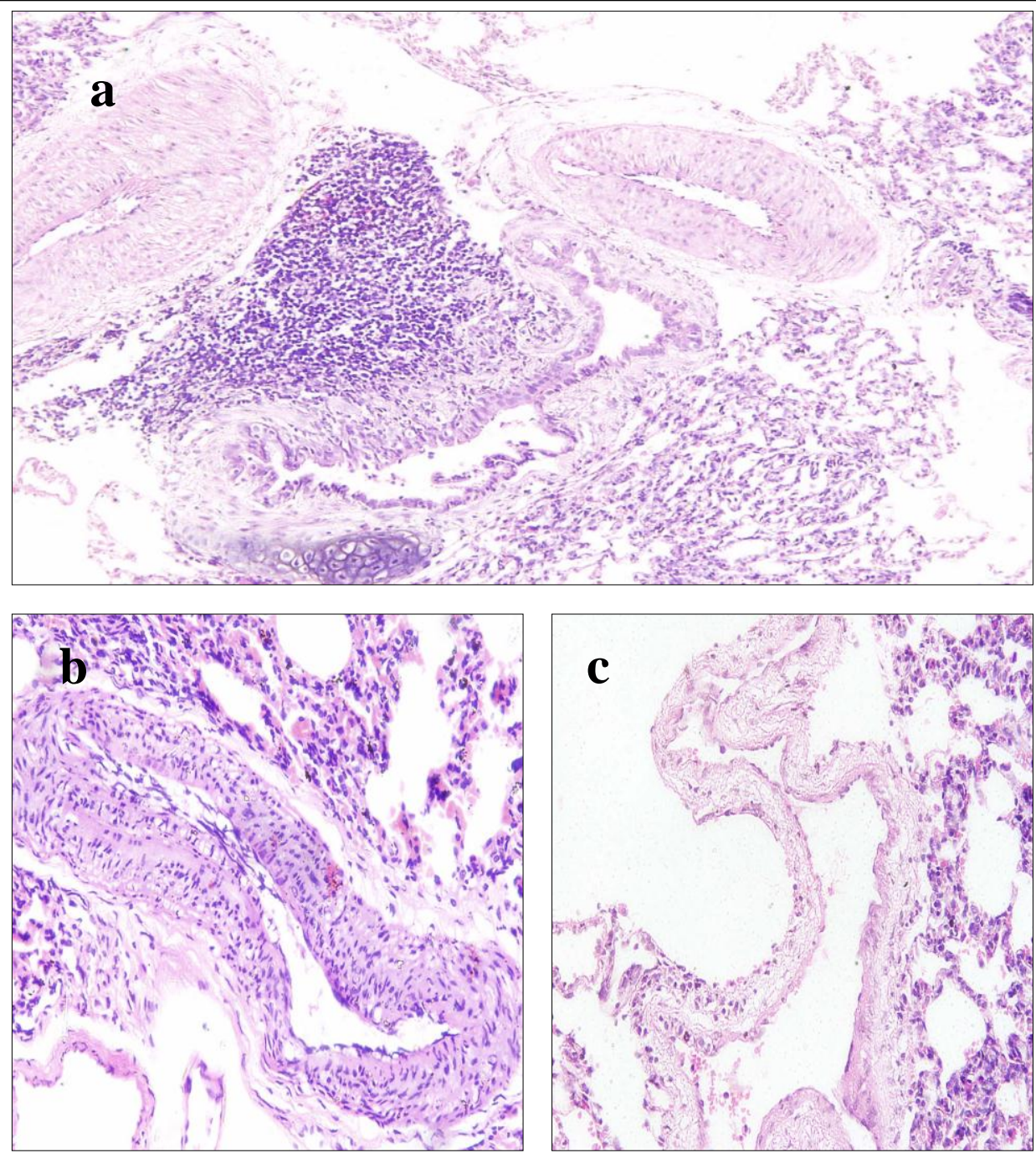

Fig. (3): Lung tissue showing (a X40) preivascular lymphoid hyperplasia, dilatation of the lymphatics tissue.

(b X200) Degenerative change at the wall of pulmonary artery, smooth muscle hypertrophy and progressive injury and necrosis.

(c X200) Endothelial degeneration of pulmonary vein, Prevascular cellular aggregation. Hematoxylin and eosin stain. 


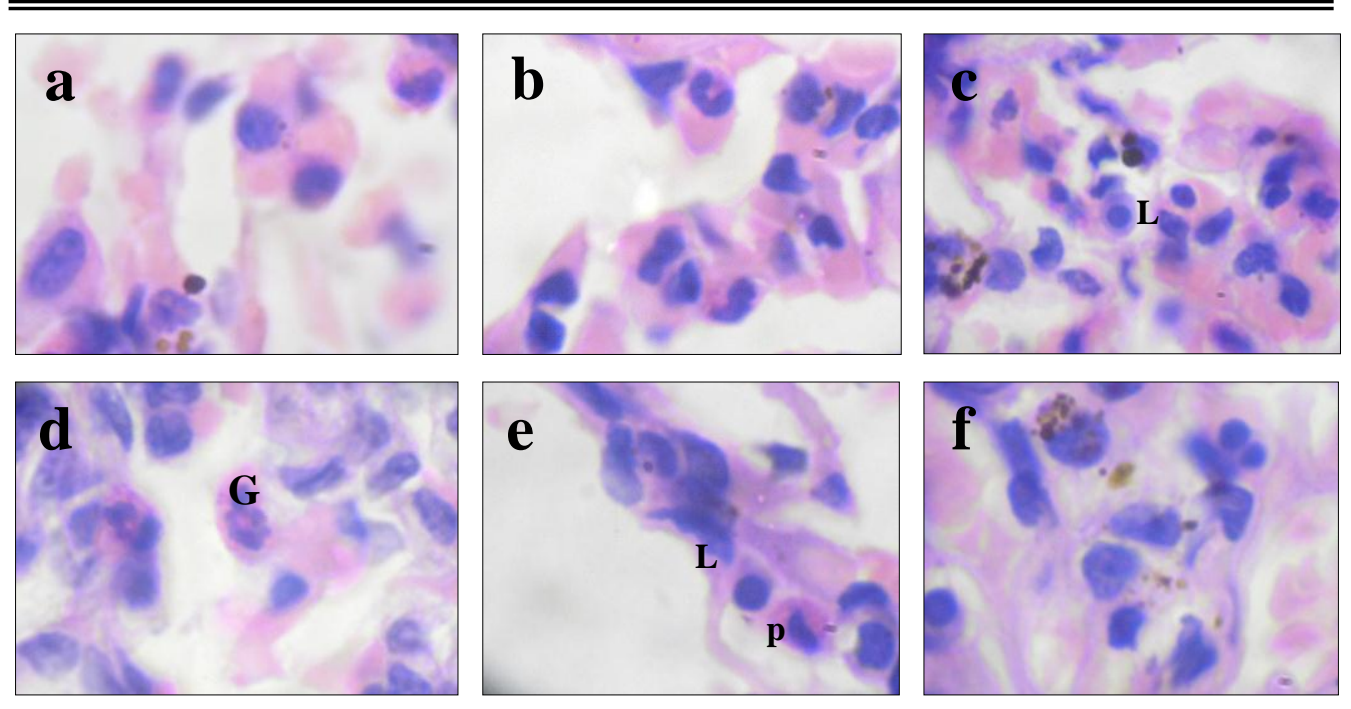

Fig. (4): Alveoli in rabbit lung showing (a) Accumulations of foamy macrophages (b) Eosinophil filled alveoli (c) Lymphocyte (d) Multinucleated giant cells (e) Lymphocyte and, plasma cells (f) increase number of platelets X1000. Hematoxylin and eosin stain.

\section{Kidney:}

The kidney showed degenerative changes in cortex and medulla, proliferation of cells inside the Bowman's capsules (Fig.5a). Mononuclear cell infiltrates were noticed (Fig. 5a\&b). The renal tubules showed signs of degeneration of epithelial cells, separation of renal epithelium from basement membrane and desquamation of the lining epithelium (Fig.5b). Focal areas of necrosis could be observed (Fig.5b). In addition renal medulla showed oedema and sever cellular degeneration with (Fig. 5c). Inflammatory cells infiltrates in the renal medulla and renal tubules revealed necrosis (Fig. 5c\&d). 
Sanaa A. El-shamy et., al.
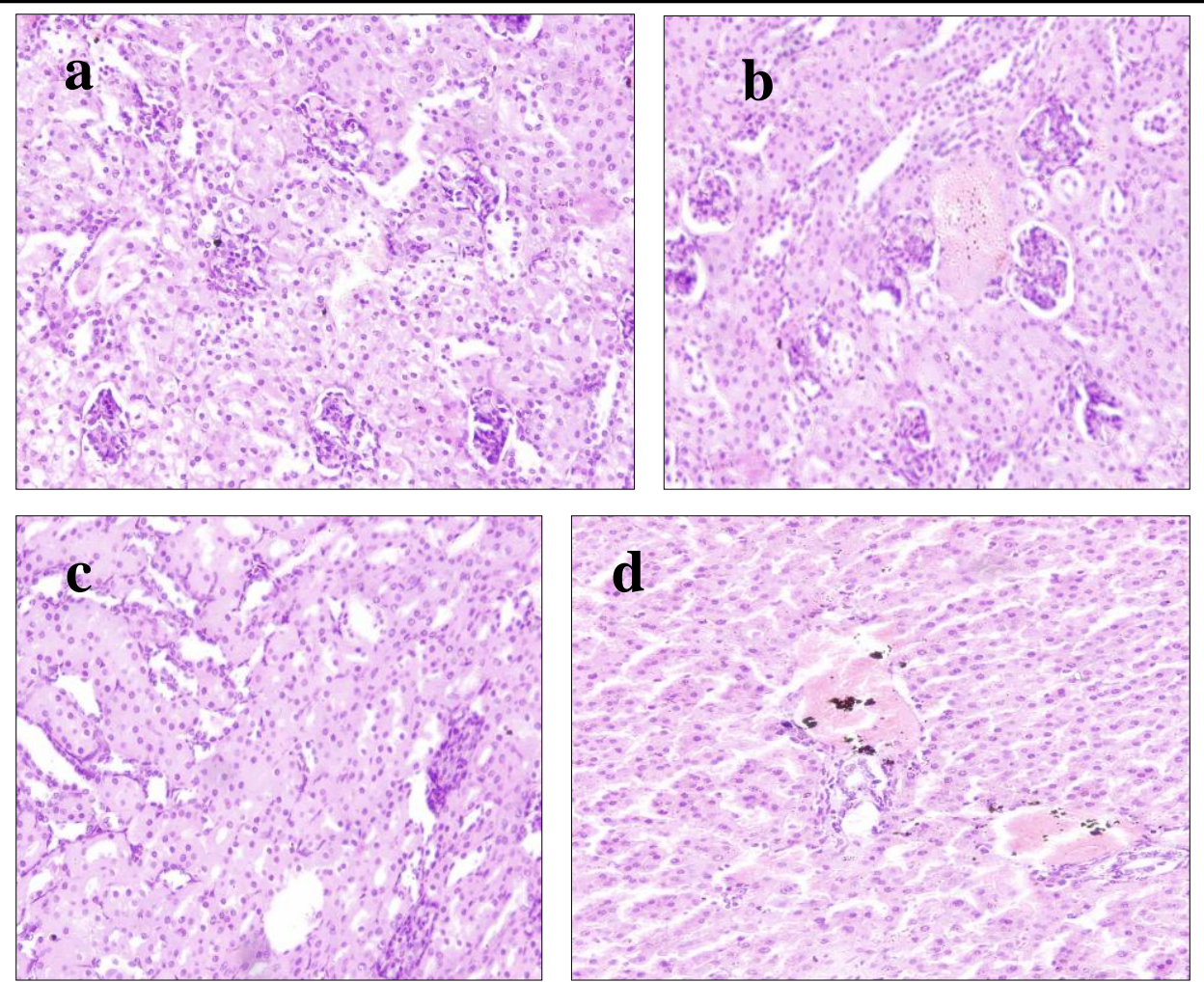

Fig. (5): Renal cortex showing $(a, b)$ proliferation of cells in the Bowman's capsules, signs of degeneration of epithelial cells at renal tubules .

(c ,d ) Glomeruli and renal tubule degeneration and focal areas of necroses at renal medulla X200 . Hematoxylin and eosin stain.

\section{Liver:}

The most prominent lesions were congested and hypereamic of hepatic parenchyma. Widening of central veins and dilated hepatic sinusoids could be seen (Fig. 6a). Extravasations of erythrocytes into the hepatic parenchyma, Focal mononuclear cellular aggregating were seen in the hepatic parenchyma and around the central vein (Fig. 6a). Portal area demonstrated congestion in hepatoportal blood vessels (Fig. 6b), randomly distributed areas of necrosis were seen (Fig. 6b). There was intercellular heamorrhage and distortion of hepatic cords (Fig. 6a \& b). 


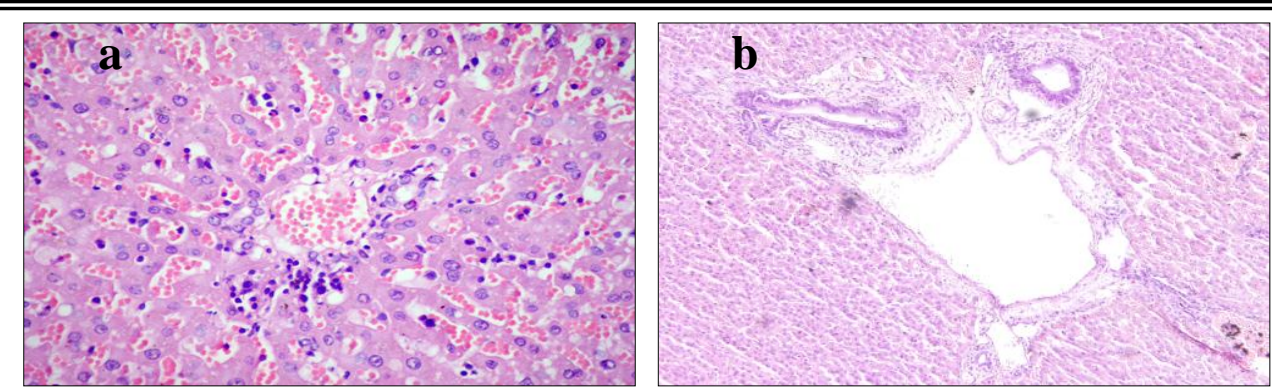

Fig. (6): Liver of infected rabbits showing (a X400) dilatation of hepatic blood sinusoid, Focal mononuclear cellular aggregating (b X40) congestion in hepatoportal blood vessels Hematoxylin and eosin stain.

\section{Spleen:}

The spleen showed no separation between white and red bulb element, some section lacks of spelenic arteries (Fig. 7a\&b). Exhaustion of lymphocytes of lymphoid follicles and depletion of hematopoietic element (Fig. 7a\&b). Marked interstial heamorrhage specialy under splenic capsule (Fig. 7c\&d).
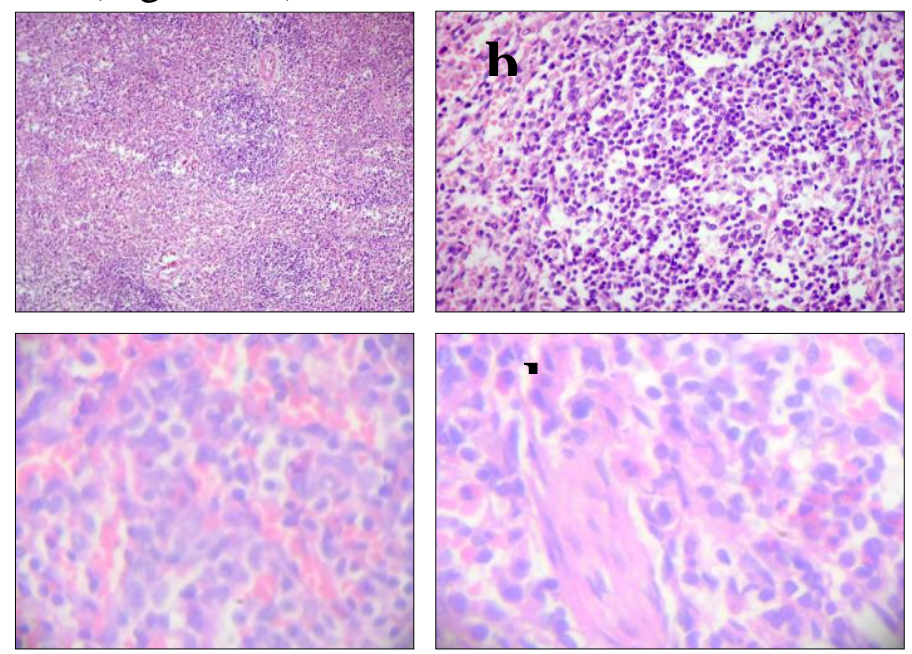

Fig. (7): Spleen of rabbit showing (aX100) no separation between white and red bulb.

(bX250) Exhaustion of lymphocytes of lymphoid follicles and depletion of hematopoietic element.

(c,dX400) Marked interstial heamorrhage specialy under splenic capsule. 


\section{DISCUSSION}

The aim of the present study was to determine the incidence of bronchopneumonia caused by Pseudomonas aeruginosa in commercial rabbits of Egypt and to develop a rapid and simple technique for the specific detection and identification of Pseudomonas aeruginosa and evaluate the histopathological lesions of such specimens. Although the classical microbiological techniques currently in use for Pseudomonas aeruginosa detection and identification are satisfactory in most situations and remain necessary for drug susceptibility testing, more rapid tests may be useful in some specific situations. Concerning the antimicrobial sensitivity pattern of Pseudomonas aeruginosa, it was shown that the organism was refractory to most chemotherapeutic agents (Brook et al., 1995).

In this study the incidence of Pseudomonas aeruginosa among diseased rabbits was seven isolates (14\%) out of 50 examined rabbits, samples including lung ( 2 isolates), heart blood (2 isolates), liver (one isolate), kidney (one isolate) and intestine (one isolate). However, Talaat (1993) recovered Pseudomonas aeruginosa from rabbits by a percentage of 10\%. Elshimaa (2007) isolated Pseudomonas aeruginosa from liver and intestine from rabbits one isolate for each.

The antibacterial susceptibility pattern of the seven Pseudomonas aeruginosa strains against eleven different antibiotics disks were highly sensitive to ciprofloxacin and tobramycin (100\%) sensitive, on the other hand, the isolates were more resistant to amoxicillin, erythromycin, and 
streptomycin with a percentage of $100 \%$ for all while, isolates showed sensitivity ranged from $85.7 \%$ to $42.85 \%$ to cefazolin, amikacin, gentamicin and colistin sulphate.

EL-Sharbagy et al., (2001) showed that Pseudomonas aeruginosa were highly sensitive to gentamicin and ciprofloxacin. However, high degree of resistance was showed to chloramphenicol, erythromycin, amoxicillin and ampicillin. Amal et al., (2002) who found that all Pseudomonas aeruginosa isolates were resistant to sulphamethaxazole/ trimethoprim with an activity percentage $100 \%$. Walaa (2004) reported that Pseudomonas aeruginosa isolates were $100 \%$ sensitive to amikacin and gentamicin. While, the isolates were $100 \%$ resistant against erythromycin and sulphamethoxazole trimethoprim she added that the isolates had variable resistance ranging from 45.45-90.9\% against ciprofloxacin, flumoquin, cefazolin and amoxicillin on the other hand They were $18.8 \%$ and $36.36 \%$ sensitive to cefazolin and ciprofloxacin respectively.

Identification of Pseudomonas aeruginosa has traditionally relied on phenotypic methods. This still is the most accurate standard when dealing with typical isolates of Pseudomonas aeruginosa. Pseudomonas aeruginosa isolates display unusual phenotypic reactions (Qin et al., 2003). Moreover, biochemical testing takes long time to perform. Molecular methods have been reported to be superior to the phenotypic methods for identification of Pseudomonas aeruginosa (Qin et al., 2003). The results of $\mathrm{PCR}$ in this study indicate that $o p r \mathrm{~L}$ gene was detected in all Pseudomonas aeruginosa strains tested with molecular weight 504 bp, so PCR assay showed 100\% sensitivity and specificity. 
This study indicates that molecular detection of Pseudomonas aeruginosa employing the oprL gene target, is a useful technique in the detection of Pseudomonas aeruginosa, there was complete agreement between molecular and conventional detection techniques. De Vos et al., (1997) reported that by designing a multiplex PCR assay based on oprI and $\operatorname{opr} \mathrm{L}$ genes for molecular detection of Pseudomonas aeruginosa showed that the specificity and sensitivity of the PCR assay were $74 \%$ and 100\%, respectively. Lavenir et al., (2007) noted that all of Pseudomonas aeruginosa strains contained the oprI and oprL genes $($ sensitivity $=100 \%$, specificity $=80 \%)$. Mohammed et al., (2012) demonstrated that PCR of 19 Pseudomonas aeruginosa strains were positive for PCR with a $504 \mathrm{bp}$.

The previous studies on histopathology by natural infection of Pseudomonas aeruginosa are rare so, the discussion in this study done comparing with the experiment animals model infection. The morbidity rate reached $30 \%$ and the mortality rate was up to $10 \%$ in the flock. Similar result recorded by Anna et al., (2006) reported significantly higher mortality rates, greater weight loss. The response of Pseudomonas aeruginosa was characterized by bronchopulmonary inflammation higher lung pathology scores, and higher inflammatory mediator and neutrophil levels, Bilateral infection was associated with higher mortality (Fick and Squier 1989;Taccetti et al,. 2005;Van Heeckeren et al., 2006 and Kukavica and Levesque 2008).

The most notable symptom at the time of death was marked respiratory distress, grossly observable confluent heamorrhagic lesions.

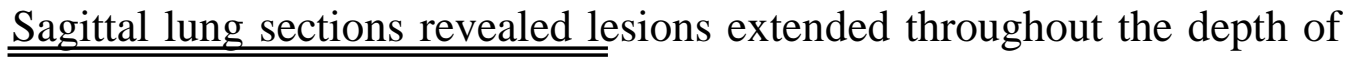
Kafrelsheikh Vet. Med. J. Vol. 11 No. 1 (2013) 
the lung. In Lung structure failed to return to normal in any of the animals examined (Gray and Kreger 1979; and wood et al., 1988). There was more intensive lung injury may contribute to the poor prognosis of pneumonia (Gosselin et al., 1998 and Van Heeckeren et al., 1997). McMorran et al., (2001) have demonstrated that infected animals have an exaggerated inflammatory response but Anna et al., (2006) disagreed with the above studies.

Although we detected the natural infection of rabbit by Pseudomonas aeruginosa in all examined farms demonstrated sever lungs injury, lesions demonstrated at both parenchyma and bronchial of lung and other organ such as liver, kidney and spleen. Pathological changes seen in animals infected were restricted to peribronchial inflammation including a dense mononuclear-cell infiltration in the alveolar spaces in addition to intra- and peribronchial inflammation (Woods et al ., 1988). But Wilson et al., (1993) examines the histology of lungs of non-immune developed a confluent heamorrhagic pneumonitis with degeneration and sloughing of the mucosa of the airways, perivascular infiltration with mononuclear cells oedema and intra-alveolar haemorrhage were prominent. The alveolar exudate is predominantly mononuclear with some polymorphonuclear leucocytes (Mays et al., 1969). Similar result obtained in the present study.

The principal microscopic finding in cases of Pseudomonas aeruginosa pneumonia after bacteraemia originating is intra-alveolar heamorrhage, alveolar septal necrosis (Fetzer et al., 1967). Few other histological studies have been carried out in animal models of 
Pseudomonas aeruginosa infection. It has been reported that Pseudomonas aeruginosa alter lung stricture and function when directly instilled into the lung of rabbits (Gray and Kreg, 1979). Wood et al., (1988) documents clearly that collapse of alveolar septal connective tissue.

The pulmonary histopathology of Pseudomonas aeruginosa infections dominated by bronchial changes including epithelial degeneration with loss of cilia, inflamed bronchial walls, bronchial lymphatic tissue hyperplasia induces bronchial narrowing. Iwata and Sato (1991) explain the mechanical narrowing of bronchiole is partly attributable to bronchial associating lymphatic tissue hyperplasia. The lumens of the bronchioli were narrowed by infiltration of neutrophils, lymphocytes, Hyperplasia of Bronchus-Associated Lymphoid Tissue occurred frequently in the peribronchial area adjacent to airways (Gray and Kreger, 1979). The airways were narrowed as a result of BronchusAssociated Lymphoid Tissue hyperplasia protruding into the bronchial lumen.

Pulmonary arteries showed smooth-muscle hypertrophy and progressive injury and necrosis, Proliferation of endothelial cells and there was a massive accumulation of lymphocytes similarly Woods et al., (1988) documents clearly that damage to pulmonary arterioles and venules but arterial-wall necrosis was not seen in the lungs. Accumulations of easinophil, macrophages, plasma cells accompanied by lymphocytes were seen around the bronchiole. Larry and Arnold (1979) reported progressive injury and necrosis of type I epithelial cells and progressively increasing accumulations of erythrocytes, plasma proteins, fibrin, and released type II epithelial cell lamellar bodies in alveolar lumina. 


\section{REFRENCES}

- Amal, A.M.; El-Taher, E.G.M. and Nashwa, A.E. (2002): Occurrence of Campylobacter jejuni and Pseudomonas aeruginosa in ewes. Egypt. Vet. Med. Vol. 62, No.2:175-185.

- Anna M., Van Heeckeren, Mark D. Schluchter, Wei Xue, and Pamela B. Davis (2006): response to Acute Lung Infection with Mucoid Pseudomonas aeruginosa in Cystic Fibrosis Mice Am. J. Respir. Crit. Care Med. Vol. 173. pp 288-296.

- Bancroft, J. D., Stevens, A. and Turner, D. R., (1996): Theory and practice of histological techniques 4th ed. Churchill Living Stone, New York Edinburgh Madrid, San Francisco, Tokyo.

- Blanco, J. E.; Blanco, M.; Blanco, J.; Rioja, L. and Ducha, J. (1994): Serotypes, toxins and antibiotic resistance of Escherichia coli strains isolated from diarrheic and healthy rabbits in Spain. Vet. Microbiol. 1994 Jan; 38(3):193-201.

- Brook, G. F.; Butel, J. S.; Ornston, L. N.; Jawetz, E.; J. L. and Adelbo, E. A.(1995): Medical Microbiology 20 th Ed., Prentice-Hall International Inc., P.218 -221.

- Buret, A.and Cripps A.W. (1993): The immunoevasive activities of Pseudomonas aeruginosa. Relevance for cystic fibrosis. Am. Rev. Resp. Dlx.; 148: 793-805.

- De Vos, D., Lim A., Pirnay JP., Struelens M., Vandenveld C. and Duinslaeger L. (1997): Direct detection and identification of Pseudomonas aeruginosa in clinical samples such as skin biopsy specimens and expectorations by multiplex PCR based on two outer membrane genes, oprI and oprL. J. Clin. Microbiol. 35: 1295-1299. 
- El-Shorbagy, M. A. ; Mosaad, A. A.; Boushra, M. H. and Mervat, M. A. (2001): Studies on Pseudomonas aeruginosa infection in quails. J. Egypt. Vet. Med. Ass., 61(1):205-221.

- EL-Shimaa, A. M., (2007): Bacteriological studies on enteric microorganisms in rabbits .M. V. Sc., Thesis, Microbiol, Fac. Vet. Med. Beni-suef. Univ. Egypt.

- Ferraro, M. J.; Craig, W. A.; Dudley, M. N.; Eliopoulos, G. M.; Hecht, D.W.; Hindler, J.(2000): Performance standards for antimicrobial disks susceptibility tests. Approved standard M2A7.Wayne, Pa: NationalCommittee for clinical lab. Standards.7.

- Fetzer, A. E., A. S. Werner, and J. W. C. Hagstrom, (1967): Pathologic features of pseudomonal pneumonia. Am. Rev. Respir. Dis. 96:1121- 1130.

- Fick, R. B. and Squier, M. D. (1989): Pathophysiologic Mechanisms in the Lung Lesion of Pseudomonas aeruginosa CHEST / 95 / 3 I MARCH, / Supplement 215S.

- Gilleland, H. E., Jr Gilleland, L. B., Mathews-Greer, J. M. (1988): Outer membrane protein F preparation of Pseudomonas aeruginosa as a vaccine against chronic pulmonary infections with heterologous immunotype strains in a rat model. Infect. Immun. 56: 1017-1022.

- Gosselin, D., Stevenson,. M., Cowley, E. A., Griesenbach, U., Eidelman, D. H., Boule, M., Tam, M. F., Kent, G. S., kamene, E., Tsui, L. C., (1998): Impaired ability of Cftr knockout mice to control lung infection with Pseudomonas aeruginosa. Am. J. Respir. Crit. Care Med. 157:1253-1262. 
- Gray L., Kreg A.(1979): Microscopic characterization of rabbit lung damage produced by Pseudomonas aeruginosa proteases. Infect. Imm., 23: 150-155.

- Hancock, R. E. and Speert, D. P. (2000): Antibiotic resistance in Pseudomonas aeruginosa ;mechanism and impact on treatment. Drug Resist Updat .,3 (4):247-255.

- Hotack, A. and Majt, N. V. (1997): Serotyping and virulence factors of Pseudomonas aeruginosa clinical isolates Acta. Micobiol. Immunol. Hng., 44 (2):141-146.

- Hyeon, J. C. ; Myeong, H. K.; Min, S. C.; Byoung, K. K.; Joo, Y. K.; Chang, K. K.; Dong, S. P.(2013): Improved PCR for identification of Pseudomonas aeruginosa. ppl. Microbiol. Biotechnol. Vol. 97, Issue 8, pp. 3643-3651.

- Iwata, M., Sato A. and H. Hayakawa, (1987): Histopathological studies of bronchus-associated lymphoid tissue (BALT) in pulmonary diseases.Jpn. J. Lymphol. 10:81-85.

- Iwata, M., Sato, A. (1991): Morphological and immunohistochemical studies of the lungs and bronchus-associated lymphoid tissue in a rat model of chronic pulmonary infection with Pseudomonas aeruginosa. Infect. Immun.: 59: 1514-1520.

- Kiska, D. L., Gilligan, P. H. (1999): Pseudomonas. En: Murray PR, Baron EJ, Pfaller MA, Tenover FC, Yolken RH, ed. Manual of clinical microbiology. $7^{\text {th }}$ edition. Washington, DC: ASM Press: 517525. 
- Kukavica-Ibrulj and Levesque, R. C. (2008): Animal models of chronic lung infection with Pseudomonas aeruginosa : useful tools for cystic fibrosis studies.rclevesq@rsvs.ulaval.ca.

- Larry, G. and Arnold. K., (1979): Microscopic Characterization of Rabbit Lung Damage Produced by Pseudomonas aeruginosa Proteases. Infection and Immunity Jan., p. 150-159 Vol. 23, No. 1.

- Lavenir, R., Jocktane, D., Laurent, F., Nazaret, S., Cournoyer, B., (2007): Improved reliability of Pseudomons aeruginosa PCR detection by the use of the specific ecfx gene target. J . Microbiol Methods .70: 20-29.

- MaFaddin, J. F.(2000): Biochemical for identification of Medical Bacteria.2 nd ed.,Waverly press,Inc., Baltimor, USA., pp.64-67 .

- Mays, B. B., G. D. Thomas, J. S. Leonard, Jr., P. M. Southern, Jr., A. K. Pierce, and J. P. Sanford. (1969). Gram-negative bacillary necrotizing pneumonia: a bacteriologic and histopathologic correlation. J. Infect. Dis. 120:687-697.

- McMorran, B. J., Palmer, J. S., Lunn, D. P., Oceandy, D., Costelloe, E. O., Thomas, G. R., Hume, D. A., Wainwright, B. J., (2001): CF mice display an abnormal host response and have impaired clearance of Pseudomonas lung disease. Am. J. Physiol. Lung Cell Mol. Physiol., 81:L740-L747.

- Mohammed, S., Salama, H. M.; Abu Shady, Mohammed, M. B. ElGameal, Mervat, G. El Anany and Ghada M. Abd-El-Rehem, (2012): Molecular Study on Relatedness between Clinical and Tap Water Isolates of Pseudomonas aeruginosa in Two Burn Units. Life Science Journal, 9 (1): 662-666. 
- Percy, D. H., S. W. Barthold, (1993): Pathology of Laboratory Rodents and Rabbits. 1:37-38, 2:85-86.

- Qin, X., Emerson, J., Stapp, J., Stapp, L., Abe, P., Burns, L., (2003): Use of real-time PCR with multiple targets to identify Pseudomonas aeruginosa and other nonfermenting gram-negative bacilli from patients with cystic fibrosis. J. Clin. Microbiol. 4: 4312-4317.

- Rahme, L. G., Tan, M.W., Le, L., Wong, S. M., Tompkins, R. G., Calderwood, S. B. \& Ausubel, F. M. (1997): Use of model plantshosts to identify Pseudomonas aeruginosa virulence factors. Proc. Nat. Acad. Sci., U. S. A., 94:13245-13250.

- Taccetti, G., Campana, S., Festini, F., Mascherini, M., Doring, G., (2005): Early eradication therapy against Pseudomonas aeruginosa in cystic fibrosis patients. European Respiratory Journal, 26: 458-61

- Talaat, W. B., (1993): Studies on Pseudomonas species isolated from farm animals. Zagazag. Vet. J., 21(1): 37.

- Van Heeckeren, A., Schluchter, M. D., Xue, W., Davis, P. B. (2006): Response to acute lung infection with mucoid Pseudomonas aeruginosa in cystic fibrosis mice. American Journal of Respiratory and Critical Care Medicine, 173: 288-96

- Van Heeckeren, A., Walenga, R., Konstan, M. W., Bonfield, T., Davis, P. B., and Ferkol, T., (1997): Excessive inflammatory response of cystic fibrosis mice to bronchopulmonary infection with Pseudomonas aeruginosa. J. Clin. Invest., 100: 2810-2815. 
- Walaa, I. A. (2004): Antibiotics resistance of Pseudomonas species isolated from fish and farm animals. M. V. Sc., Thesis, Microbiol, Fac. Vet. Med. Alex. Univ. Egypt.

- Walker, T. S., (1998): Microbiology. Philadelphia (PA): OWB Saunders; 173-181.

- Wiener-Kronish, J. P., Sakuma, T., Kudoh, I., Pittet, J. F., Frank, D., Dobbs, L.,Vasil, M. L., and Matthay, M. A., (1993): Alveolar epithelial injury and pleural empyema in acute P. aeruginosa pneumonia in anesthetized rabbits. J. Appl. Physiol., 75: 1661-1669.

- Wilson NR, Dunkley, ML, Buret A, Young B and Cripps $\boldsymbol{A} \boldsymbol{W}$ (1995): Histopathology of the lung following intratracheal challenge with live Pseudomonas aeruginosa in intestinally immunized rats, Immunology and Cell Biology 73, 440-445.

- Woods, D. E., Hwang, W. S., Sharabadi, M. S. and Que, J. U., (1988): The Pathological Society of Great Britain and Ireland Alteration of pulmonary structure by Pseudomonas aeruginosa exoenzyme S J. Med. Microbiol. Vol. 26: 133-141.

- Woods, D. E, Sokol, P. A., (1986): Role of Pseudomonas aeruginosa extracellular enzymes in lung disease. Clinical and Investigative Medicine, 9: 108-112.

- Xu, J.; Moore, J. E.; Murphy, P. G.; Millar, B. C. and El-born, J. S. (2004): Early detection of Pseudomonas aeruginosa - comparison of conventional versus molecular (PCR) detection directly from adult patients with cystic fibrosis (CF). Annals of Clinical.Microbiol.,3(21). 
در اسات باثولوجية وبكتريولوجية على الالتهاب الثعبى الرئوى بميكروب السيدومونس ائس

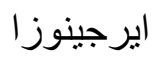

فى الأر انب التجارية بمحافظة الإسكندرية.

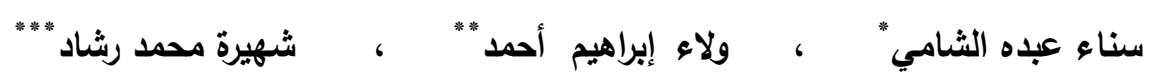

معهر بحوث صحة الحيوان-" قسم الباثولوجى ، "قتم البكتريولوجى - الإسكندرية ، *** قسم الباثولوجي- أسيوط

أجريت هذه الدراسة للوقوف على مدى أنتشار عدوى الارانب بميكروب السيدومونس إيرجينوزا و

ذلك بعزل و تصنيف العترات من الارانب التى كانت تعانى من أعراض تتفسية كما تم أجراء أختبار الحساسية للعترات المعزولة ـ هذا و قد تم أستخدام تفاعل البلمرة المنسلسل (PCR) كطريقة حديثة من طرق التشخيص المعطية و كانت النتائج كالاتى: بالفحص البكتيرى لاجمالى عدد 50 أرنب من خمسة مزارع تجارية مختلفة فى محافظة الاسكندرية. تم عزل ميكروب السيدومونس ايرجينوزا بنسبة 14\% ( 74 عترات ) حيث سجلت الرئه، القلب أكبر نسبه من العترات المعزوله (2 عترة لكلا منهما) يليها الكلى، الكبد ، الأمعاء (عترة لكلا منهما) ـ وقد تم أجراء اختبار الحساسيه لعترات السيدومونس إيرجينوزا ( 7

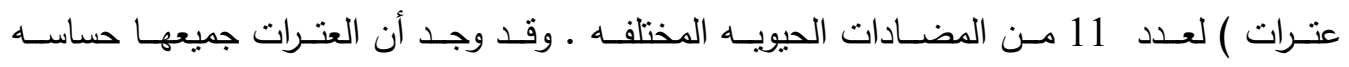
للسيبروفلوكاسسين، التوبراميسين بنسبه 100\% يليها السيفازولين ، الاميكين، الجنتاميسين، الكولستين سلفات بنسبه 85,7\% ، 71.4\%،71.4\%؛ 42.85\% على التوالى. وكانت العترات المعزولـه أكثر مقاومـه للمضات الحيويـه التاليه: الاموكسيلين، الاريثروميسين، الاستربتوميسين بنسبه 100\% كلا منهم يليهم كلورمفينيكول بنسبه 85.7\%، كولستين سلفات بنسبه 28.75\%، جنتاميسين 28.75\% الترايميثوبرايم سلفاميثازول 85.7\%، سيفازولين 14.28\% و الاميكين 14.28\% أوضحت العترات المعزولـه حساسـيه متوسطه للكولستتين سـلفات بنسبة 28.75\% يلـي الاميكين ، الكلورمفينيكول ؛ Kafrelsheikh Vet. Med. J. Vol. 11 No. 1 (2013) 
الترايمينوبرايم سلفاميثازول بنسبه 14.28\%، لكلا منهم. لعزل وتصنيف ميكروب السيدومونس إيرجينوزا تم أستخدام منابت تغذية مختلفة كما تم أستخدام الطرق التقليدية البيوكيميائية للتصنيف بالأضافة إلى أستخدام طريقة التصنيف البيوكيميائية الحديثة (API20E) ووجد تطابق وتوافق بين الطريقتن. وقد تم oprL إجراء تفاعل البلمرة المتسلسل لعدد 7 من عترات السيدومونس ايرجينوزا المعزوله بأستخدام gene وقد تبين ان العترات كانت إيجابيه لهذا التفاعل وكانت جميعها تحمل أوزان جزئيه 504بيزبير. الصفة التشريحية للرئتين اظهرت مظاهر الاحتقان والارتتشاح، مناطق مصفرة ومناطق نزفية ومتورمة ـ تتكرز متعدد البؤر في الرئة والكبد والكلى والطحال. أظهر الفحص المجهري للرئة وجود تغيرات في الحويصلات الهوائة والثعب الهوائية. نزف داخل الرئة وارتثاح، وارتثاح للخلايا وحيدات النواة مع تضخم ليمفاوي واتساع في الحويصلات الهوائية مع تهتلك للانسجة. الأوعية الدموية الرئوية تحاط بها الخلايا وحيدات النوى وقد أظهرت الثرايين الرئوية تضخم العضلات الملساء وتتكرز، تلف للخلايا الطلائية، وكذا تراكم للخلايا المبطنة للاوردة. كانت جدران الثعب والثعيبات الهوائية سميكة امـا الخلايا المبطنة فقد فقدت الأهداب مـع تهتك لخلايـا الغدد. وجدت زيادة في خلايـا اليمفوسيت والبلازما والايزينوفيل وخلايـا الميكروفاج والخلايـا المتعددة الانويـة. اظهرت الكلي تغيرات في القتـرة والنخاع وبعض الكبيبات منكمشة و بها تراكم للخلايا داخل حافظة بومان مع تتكرز في الانابيب البولية اما التغيرات في الكبد تمثلت في احتقان مع اتساع للجيوب الدموية والأوردة المركزية والجيوب الكبدية مع نزيف بين الخلايا واظهر الطحال انفصال بين اجزائة و نزيف خاصة تحت الحافظة. 